\title{
HIV vulnerability among CAPSad users: Relationship between beliefs and health behaviors
}

\author{
Rafael N. Furtado', Leonardo F. Martins², and Fabiane R. dos S. Grincenkov' \\ ' Postgraduate Program in Psychology, Federal University of Juiz de Fora (UFJF) \\ ${ }_{2}^{2}$ Postgraduate Program in Clinical Psychology, Pontifical Catholic University of Rio de Janeiro
}

Received: March 25 $5^{\text {th }}, 2020$.

Accepted: May $18^{\text {th }}, 2021$.

\section{Author Note}

Rafael N. Furtado (D) https://orcid.org/00oo-0002-5624-2602

Leonardo F. Martins (D) https://orcid.org/00oo-0002-0941-6294

Fabiane R. dos S. Grincenkov (D) https://orcid.org/00oo-0003-0948-2635

Correspondence concerning this article should be addressed to Rafael Nogueira Furtado, Programa de Pós-Graduação em Psicologia da Universidade Federal de Juiz de Fora, Instituto de Ciências Humanas, Campus Universitário, Rua José Lourenço Kelmer, São Pedro, Juiz de Fora, MG. Brazil. CEP 36036-900o.E-mail: rnfurtado@yahoo.com.br 


\begin{abstract}
The abuse of alcohol and other drugs is an important mental health issue in the adult and adolescent population. Along with other concerns, substance use can be associated with a higher vulnerability to HIV infection. This study aimed to assess the relationship between three variables in substance users: HIV perceived severity, condom use self-efficacy, and HIV vulnerability. This was a cross-sectional, quanti-qualitative study on outpatients from a Psychosocial Care Center for Alcohol and Other Drugs (CAPSad) in Brazil. Our findings indicate no significant association between HIV perceived severity and HIV vulnerability (Spearman's $\rho$ of -0.109 and $p$-value of 0.507), and a marginally significant negative association between condom use self-efficacy and HIV vulnerability (Spearman's $\rho$ of -0.302 and p-value of 0.061). In this paper, we discuss the stigma related to HIV/aids and criticize fear-based preventive interventions, recommending against them. On the other hand, we propose strategies for self-efficacy development, aiming to strengthen the autonomy of CAPSad users.

Keywords: HIV/aids, substance use, health beliefs, stigma, psychosocial attention
\end{abstract}

\title{
VULNERABILIDADE AO HIV ENTRE USUÁRIOS DE CAPSAD: CRENÇAS E COMPORTAMENTOS EM SAÚDE
}

\begin{abstract}
Resumo
O abuso de álcool e outras drogas é uma importante questão de saúde mental para a população adulta e adolescente. Entre os eventos associados a esse abuso, encontra-se elevada vulnerabilidade ao HIV. O presente estudo buscou avaliar, em usuários de substâncias, a relação entre: gravidade percebida do HIV, autoeficácia para uso de preservativo e vulnerabilidade ao HIV. Trata-se de um estudo transversal, quanti-qualitativo, com usuários de um Centro de Atenção Psicossocial para Álcool e Outras Drogas (CAPSad) no Brasil. Os resultados indicam não haver associação significativa entre gravidade percebida do HIV e vulnerabilidade ao HIV ( $\rho$ de Spearman de -0,109 e valor- $p$ de 0,507). Contudo, foi identificada uma associação negativa marginalmente significativa entre autoeficácia para uso de preservativo e vulnerabilidade ao HIV ( $\rho$ de Spearman de $-0,302$ and valor- $p$ de 0,061). Neste artigo, discutimos o estigma relacionado ao HIV/aids e realizamos uma crítica a intervenções baseadas no medo, recomendando contra seu uso. Em contrapartida, são propostas estratégias para o desenvolvimento da autoeficácia, de modo a fortalecer a autonomia dos usuários de CAPSad.
\end{abstract}

Palauras-chave: HIV/aids, uso de substâncias, crenças em saúde, estigma, atenção psicossocial

\section{VULNERABILIDAD AL VIH ENTRE USUARIOS DE CAPSAD: CREENCIAS Y COMPORTAMIENTOS EN SALUD}

\section{Resumen}

El abuso de alcohol y otras drogas es un importante problema de salud mental para la población adulta y adolescente. Entre los eventos de salud a ele asociados, se encuentra elevada vulnerabilidad a infección por VIH. El estudio buscó evaluar la relación entre: gravedad percibida del VIH, autoeficacia para 
el uso del condón y vulnerabilidad a el VIH. Este es un estudio transversal, cuanti-cualitative, con usuarios de un Centro de Atención Psicosocial para el Alcohol y Otras Drogas (CAPSad) en Brasil. Los hallazgos indican ausencia de asociación entre gravedad percibida del $\mathrm{VIH}$ y vulnerabilidad a el VIH ( $\rho$ de Spearman de -0,109 y valor- $p$ de 0,507); y una asociación negativa marginalmente significativa entre esta última variable y autoeficacia para el uso de condón ( $\rho$ de Spearman de -0,302 y valor- $p$ de $0,061)$. En este trabajo discutimos el estigma relacionado con el VIH/sida y criticamos las intervenciones basadas en el miedo, recomendando contra su uso. Por otro lado, se proponen estrategias para el desarrollo de la autoeficacia, con el fin de fortalecer la autonomía de los usuarios del CAPSad.

Palabras clave: VIH/sida, abuso de sustancias, creencias en salud, estigma, atención psicosocial 
The United Nations Office on Drugs and Crime (UNODC, 2020) estimates that, in 2018, around 269 million individuals worldwide had consumed drugs at least once in their lifetime. This prevalence corresponds to $5.4 \%$ of the global population aged between 15 and 64 or, in other terms, to 1 in every 19 people. The report indicates an increase of $12 \%$ in the global prevalence for drug use for the last decade (from $4.8 \%$ in 2009 to $5.4 \%$ in 2018), as well as an increase in drug variety and potency (UNODC, 2020).

Drug use can negatively impact psychological, biological, and social functioning. The most recent Global Burden of Disease Study (GBD) showed that, in 2017, 585,000 deaths occurred globally due to the consumption of drugs, representing the loss of 42 million disability-adjusted life years (DALYs). Among the many substances, opioids are accounted for the highest burden of diseases (GBD 2017 Risk Factors Collaborators, 2018).

In Brazil, mental health assistance for substance use disorder is provided by a set of services, one of them being the Psychosocial Care Centers for Alcohol and Other Drugs (CAPSad). These centers are open to the community and their multidisciplinary teams offer psychological and psychiatric support to substance users and their families. To assure the integral care of substance users, CAPSad also provides general health assistance and promotes social reintegration by strengthening community ties and work/educational rehabilitation.

Among the health issues associated with the use of alcohol and other drugs is the higher vulnerability to infectious pathogens, such as the Human Immunodeficiency Virus (HIV). The Joint United Nations Programme on HIV/aids (UNAIDS, 2020) states that 1.7 million people were infected with HIV in 2019 alone. This incidence is three times above the threshold of 500,000 new infections established by UNAIDS for the year 2020. With respect to the global population living with HIV, the prevalence was around 38 million individuals (all ages) in 2019 (UNAIDS, 2020). Regarding Brazilian substance users, the HIV Biological and Behavioral Surveillance Survey (BBSS), conducted by the Ministry of Health, found that the HIV prevalence rate among this population was 5.8\% (Baptista et al., 2018).

HIV vulnerability among substance users can be explained by the interaction of social, programmatic, and individual factors.

In 2019, the Brazilian Ministry of Health ran a prevention campaign, in which the severity of sexually transmitted infections (STIs) was emphasized as a strategy to promote condom use (Brasil, 2019). The campaign consisted of advertising videos with young people reacting with fear and disgust when presented to symptoms of STIs. After highlighting the aversiveness of STIs, a message was shown by the campaign: "without a condom, you take this risk" (Brasil, 2019).

Aiming to assess the existence of a negative correlation (inversely proportional) between perceived severity of HIV and exposure to the virus, we initially conducted a systematic bibliographic review. The findings for such association were mixed (Furtado et al., 2020). 
Fifty observational studies, published between 1998 and 2018, were analyzed and 26 papers were included in the synthesis of the review. Seventeen of these studies did not find the expected correlation between perceived severity and HIV exposure, against 9 studies in which such correlation was identified. Despite mixed results concerning HIV perceived severity, most studies found a significant negative association between condom use self-efficacy and HIV exposure (Furtado et al., 2020). The Health Belief Model posits that decisions made by an individual concerning health are derived from basic beliefs, such as the perceived capability of oneself to perform preventive measures (i.e., self-efficacy) (Rosenstock et al., 1994).

Considering the importance of preventing HIV among substance users, the present study critically assessed both the relationship between HIV perceived severity and HIV exposure, and the relationship between condom use self-efficacy and HIV exposure in outpatients of a CAPSad unit, in the city of Juiz de Fora, state of Minas Gerais (MG), Brazil. Providing comprehensive healthcare to substance users is needed and targeting beliefs adequately may be a useful strategy for HIV prevention in mental health services.

\section{Method}

This was a cross-sectional, quanti-qualitative study on the relationship between HIV perceived severity and HIV exposure, and the relationship between condom use self-efficacy and HIV exposure. The Research Ethics Committee at the Federal University of Juiz de Fora approved the study, registered under number CAAE 91971018.0.0000.5147.

\section{Participants}

The inclusion criteria for participants were: 1) being 18 years old or older; and 2) having a stable bond with the CAPSad unit where our study took place. We considered users with a stable bond to be those for whom individualized treatment plans had already been prepared and who were integrated within the institution's activities. As for the exclusion criteria, they were: 1) presenting cognitive and behavioral alterations which hindered the conduction of interviews; and 2) being HIV-positive. All information about serostatus was self-declared, given that no HIV test was performed.

A total of 52 participants were recruited using a convenience sampling method between August and December 2018. In our study, this method led to a heterogeneous group of participants regarding sex and age (ranging from 21 to 70 years old). Convenience sampling consists of a non-probabilistic research method, by which all available participants are invited to deliberately join the study. Sex and age heterogeneity were a characteristic of this CAPSad population, where all patients (men and women older than 18) shared the same therapeutic groups and activities. However, it must be highlighted that convenience sampling and sex/age heterogeneity limits the generalization of our findings, as it will be properly pointed ahead. 
From the sample of 52 participants, ten individuals were selected to participate in the pilot study. The pilot study allowed us to assess the adequacy and comprehensibility of the data collection instruments and the qualitative interview. Additionally, three participants were eliminated due to the exclusion criteria, resulting in a final sample of 39 individuals.

\section{Instruments}

Data were collected from three instruments combined with a semi-structured interview. The instruments were "Perceived Severity Scale", by which we assessed HIV perceived severity; "Condom Self-Efficacy Scale", by which we assessed condom use self-efficacy; and "CRA Questionnaire", by which we assessed HIV exposure behaviors.

Perceived severity is defined in the present study as thoughts on the seriousness of contracting HIV and includes "both medical and clinical consequences (e.g., death, disability, and pain) and possible social consequences (such as effects of the conditions on work, family life, and social relations)" (Rosenstock et al., 1994, p. 8). The "Perceived Severity Scale" is a Brazilian version of Champion's (1984) "Seriousness Scale", adapted by Dela Coleta (2003). The instrument is a 12-item measure for evaluating beliefs regarding the severity of health disorders, and scores were determined using a Likert scale. The Cronbach's a obtained by Champion (1984) for the "Seriousness Scale" was 0.78 , and the coefficient obtained by Dela Coleta (2003) for the Brazilian instrument was 0.81.

The second instrument we used was the Brazilian version of the "Condom Self-Efficacy Scale," originally developed by Hanna (1999). The instrument is based on Bandura's (1977) social learning theory and assesses one's confidence in using condoms. According to Bandura (1977), self-efficacy refers to people's beliefs about their ability to exercise control over their motivation, behavior, and social environment. Condom use self-efficacy is operationalized as beliefs about one's own ability to, for example, use condoms in stressful situations, convince one's sexual partner to use condoms, and refuse sex in the absence of condoms. Hanna's "Condom Self-Efficacy Scale" was translated and validated for a Brazilian population by Sousa et al. (2017) and consists of 14 items scored using a Likert scale. The Cronbach's a for the original scale was 0.85 for a sample of 209 adolescents and young adults (13 to 26 years of age). For a similar Brazilian sample (209 adolescents and young adults, 13 to 26 years of age), a coefficient of 0.85 . was obtained (Sousa et al., 2017).

The third instrument was the "CRA Questionnaire". It is the Brazilian version of the "Risk Assessment Battery" proposed by Metzger (1993), which was translated and validated for Brazilian Portuguese users by Pechansky et al. (2002). Metzger (1993) obtained a Cronbach's a of 0.75 for the Risk Assessment Battery in a population of heroin users. The CRA Questionnaire presents 19 multiple-choice questions, which determine an overall score for the respondent (higher scores indicating higher HIV exposure). The CRA Questionnaire pro- 
vides this score by assessing the following behaviors: consumption of alcohol and other drugs (substance type, frequency, and routes of administration); sexual intercourse (frequency, number, and serostatus of partners); exchange of sex for drugs/money; condom use; and HIV testing.

In addition, we used a sociodemographic questionnaire, and a semi-structured qualitative interview was conducted. This qualitative procedure explored HIV-related perceptions based on the following questions: what do you think about HIV/aids? do you think HIV/aids is a serious matter? what are your thoughts on condoms? and what do you believe are the benefits and difficulties of using condoms? Interviews were recorded and later transcribed. We clarified all questions that participants had regarding the study, and participants also provided informed consent before the interview took place. No secondary sources of data from CAPSad were used.

\section{Data analysis}

Data obtained from the Perceived Severity Scale, CRA Questionnaire, and Condom Self-Efficacy Scale were quantitatively analyzed using the SPSS version 15.0 software program. First, a descriptive analysis of sociodemographic and psychosocial data was performed, calculating means, standard deviations, medians, and maximum and minimum values. An analysis of data normality (using the Kolmogorov-Smirnov test) was also performed for the following variables: a) HIV perceived severity; b) condom use self-efficacy; and c) HIV exposure behaviors. Data distribution indicated that Spearman's coefficient should be used in the correlation tests. For all inferential analyses, we considered a $95 \%$ confidence interval for the estimations.

Regarding the qualitative data, interviewees' responses to questions on HIV-related beliefs and behaviors were analyzed for content according to the approach suggested by Bardin (2011). Following the three steps of content analysis (pre-analysis, exploration of the material, and treatment of the results), we identified common conceptions and themes from the interviews and classified them to identify patterns in the responses. In addition, we compared the interviews' data with the scores in the Perceived Severity Scale and Condom Self-Efficacy Scale in order to identify common beliefs reported by the extreme high and low cases. The aim of the qualitative analysis was to explore the data obtained from the quantitative instruments. Each participant was identified by a code: the letter $\mathrm{P}$, followed by the number of the interview.

\section{Results}

Sociodemographic data are displayed in Table 1 and Table 2. Descriptive data on the perceived severity of HIV, HIV exposure, and condom use self-efficacy scales are shown in Table 3. Table 4 shows inferential statistics, presenting correlation coefficients and $p$-values 
for the perceived severity of HIV and HIV exposure and between the latter and condom use self-efficacy.

\section{Table 1}

Sociodemographic characteristics of participants $(n=39)$

\begin{tabular}{|c|c|}
\hline Variables & n (\%) \\
\hline \multicolumn{2}{|l|}{ Age } \\
\hline 21 to 70 (mean: 41.8 ) & $39(100 \%)$ \\
\hline \multicolumn{2}{|l|}{ Sex } \\
\hline Female & $9(23.1 \%)$ \\
\hline Male & $30(76.9 \%)$ \\
\hline \multicolumn{2}{|l|}{ Level of Education } \\
\hline Uneducated & 0 \\
\hline Did not complete Elementary School & $22(56.4 \%)$ \\
\hline Completed Elementary School & $4(10.3 \%)$ \\
\hline Did not complete High School & $5(12.8 \%)$ \\
\hline Completed High School & $6(15.4 \%)$ \\
\hline Did not complete Higher Education & 0 \\
\hline Completed Higher Education & $2(5.1 \%)$ \\
\hline \multicolumn{2}{|l|}{ Relationship Status } \\
\hline Single or unaccompanied & $29(74.4 \%)$ \\
\hline Married or in a stable relationship & $8(20.4 \%)$ \\
\hline Undefined relationship status & $2(5.2 \%)$ \\
\hline \multicolumn{2}{|l|}{ Employment status } \\
\hline Steady job (daily) & o \\
\hline Freelance work (sporadic) & $9(23.1 \%)$ \\
\hline No occupation & $30(76.9 \%)$ \\
\hline \multicolumn{2}{|l|}{ Income } \\
\hline Up to monthly minimum wage (MMW) & $20(51.3 \%)$ \\
\hline 01 to $03 \mathrm{MMW}$ & $7(18.1 \%)$ \\
\hline 04 to $06 \mathrm{MMW}$ & $1(2.6 \%)$ \\
\hline 07 to $09 \mathrm{MMW}$ & 0 \\
\hline Equal or higher than $10 \mathrm{MMW}$ & 0 \\
\hline Has no income & $11(28 \%)$ \\
\hline
\end{tabular}




\section{Table 2}

Participants' answers to the questions on the sociodemographic questionnaire $(\mathrm{n}=39)$

\begin{tabular}{lc}
\hline \multicolumn{1}{c}{ Questions } & $\mathbf{n}(\%)$ \\
\hline Have you received any advice on how to use condoms here in this CAPSad unit? & $17(43.6 \%)$ \\
Yes & $22(56.4 \%)$ \\
No & $4(10.3 \%)$ \\
Have you heard about PEP* or PrEP** in this CAPSad unit? & $35(89.7 \%)$ \\
Yes & $20(51.3 \%)$ \\
No & $19(48.7 \%)$ \\
Have you received advice on not sharing needles/syringes in this CAPSad unit? & \\
Yes & $18(46.2 \%)$ \\
No & $21(53.8 \%)$ \\
Yes & \\
No &
\end{tabular}

Note. $*$ PEP $=$ Post-Exposure Prophylaxis $/ * *$ PrEP $=$ Pre-Exposure Prophylaxis.

\section{Table 3}

Descriptive statistics of the Perceived Severity Scale, CRA Questionnaire, and Condom Self-Efficacy Scale $(\mathrm{n}=39)$

\begin{tabular}{lccccc}
\hline \multicolumn{1}{c}{ Variables } & Mean & SD* & Median & $\begin{array}{c}\text { Minimum } \\
\text { Value }\end{array}$ & $\begin{array}{c}\text { Maximum } \\
\text { value }\end{array}$ \\
\hline Perceived Severity Scale & 49.97 & 9.03 & 54.00 & 27.00 & 60.00 \\
CRA Questionnaire & 13.59 & 6.27 & 13.00 & 3.00 & 26.00 \\
Condom Self-Efficacy Scale & 53.97 & 12.90 & 56.00 & 19.00 & 70.00 \\
\hline
\end{tabular}

Note. $*$ SD $=$ Standard Deviation.

\section{Table 4}

Correlation coefficients between perceived severity of HIV and condom use self-efficacy and HIV exposure $(n=39)$

\begin{tabular}{lcc}
\hline \multicolumn{1}{c}{ Variables } & \multicolumn{2}{c}{ HIV exposure } \\
\cline { 2 - 3 } & Spearman $\boldsymbol{\rho}$ & $\boldsymbol{p}$-value* \\
\hline Perceived severity of HIV & -0.109 & 0.507 \\
Condom use self-efficacy & -0.302 & 0.061 \\
\hline
\end{tabular}

Note. ${ }^{*}$ Significance value: $p<0.05$. 
For HIV perceived severity and HIV exposure, we found a correlation coefficient of -0.109 , with a $p$-value of 0.507 . Therefore, no significant correlation between the two variables was observed. Regarding condom use self-efficacy and HIV exposure, the correlation coefficient found was -0.302 , indicating a negative relationship between the variables; thus, as self-efficacy increases, vulnerability decrease. The $p$-value for this correlation was 0.061 , slightly higher than the usually adopted significance level $(p<0.05)$, which would not exclude it as marginally significant, however.

Regarding qualitative data, responses were classified into three categories: 1) "conceptions of HIV/aids," 2) "perceived severity of HIV/aids," and 3) "beliefs about benefits and barriers to condom use". The most frequently reported beliefs from the first category (conceptions of HIV/aids) were as follows: HIV is easy to prevent; there is a lot of protection nowadays; HIV/aids is a very sad disease; HIV infection happens due to carelessness; and death would be on one's mind if they became infected with HIV. Many participants also had conflicting knowledge about HIV treatment. Some participants believed that HIV/aids are treatable conditions, that no one dies of HIV/aids if properly treated, and that people can live normally with HIV/aids. However, some interviewees considered that treatments are not yet available, that HIV/aids can be treated with antibiotics, and that there is a cure for it, as the excerpts show:

This is a sad disease. It takes people's lives and there is no treatment for it, no remedy. [...] It destroys the person, the person is no longer happy, because one will not be able to have a relationship anymore. If people with HIV have a relationship, they will kill other people. I will not want a mate once she will die because of me (P32).

People are to blame for this disease, right?! There is a lot of protection nowadays. If people do not protect themselves, it's because they don't want to. If that happens to me, I will find a way to end my life or something (P29).

Even if a person has the HIV virus, they can have a normal life, the person does not have to think that life is over [...] Taking the correct medicine, she can have a normal life like any other (P11).

HIV is a virus, and aids is already the disease. There is no way to go back. If that happens, it is over. There is no remedy. In my opinion, there is no medicine for it (P32).

I think the treatment for HIV is strong. If you catch it, you must go to the doctor to take Benzathine [benzylpenicillin]. Benzathine kills it (P18).

Nowadays, HIV is curable, different from the past when it was not (P13). 
As for the second category (beliefs on HIV severity), most participants indicated they viewed HIV as a serious matter, described by some as something "terrible". Many participants also held beliefs grounded on social stigmas associated to HIV. When comparing the interviews with the participants' scores on the Perceived Severity Scale, we observed that respondents with the highest scores commonly reported: fear of contracting HIV; concern that their lives would change completely if they had HIV; and beliefs that the severity of HIV is greater than the severity of other illnesses, such as cancer. As expressed by the respondents:

I think it is a serious thing, isn't it?! I see a lot of talk on television and people commenting about it. I have two friends who found out that they were HIV positive. They got very thin, started taking a lot of medicine, things like that. That is how I see it, it kills people (P15).

I was religious and there were people I knew from the church. People my age, who were like me, many of them I knew for a long time, many who attended to the same congregation. I had sex with them without a condom, and I never had any problem (P04).

I think that a person who gets HIV will never have peace in life again. You will remember every day that you have HIV. This is worse than cancer [...] If I were to choose between HIV and cancer, I would choose cancer (P22).

Concerning participants with the lowest scores in the Perceived Severity Scale, the most frequently reported beliefs were that HIV/aids is treatable, that there is medicine for them, and it is possible to live normally with HIV/aids. Notably, a participant with low score on the Perceived Severity Scale stated that HIV/aids is a severe and incurable disease, but it can be managed with treatment. Meanwhile, another low-score participant said he did not know the difference between HIV and aids, also responding that everybody in CAPSad should be tested for HIV.

In my opinion, even if your partner is positive and you're not, you can have a normal life, a normal relationship, since you use condom and your partner takes the medication [...] People don't have to think life is over, they can be treated and have a normal life like anyone ( $\mathrm{P} 11$ ). It is a serious illness, without a doubt. I think it is a disease that kills you because there is no cure for it, but there are drugs for it. So, if it happens that a person gets HIV, just start taking the drug cocktail and go on with your life (P21).

I do not know what the difference between HIV and aids is. So, you can have the virus for life and the virus does not turn into aids? But can you transmit the virus? Nice. I did not know that. It was all the same to me (P39). 
This CAPS unit should test everyone for HIV. Not only for HIV but for other diseases such as syphilis and anemia. I remember once they tested people here for blood sugar. Maybe someone has something and is unaware of it (P39).

Regarding the third category (beliefs about benefits and barriers to condom use), we identified the following perceived benefits: STD prevention, condoms used as a contraceptive method, and condoms as a way to make sexual intercourse more peaceful or pleasant. The most frequently reported difficulties with condom use were: immaturity when they were younger; substance use (which they thought impaired their judgment); impulsivity; unavailability of a condom at the moment of intercourse; loss of pleasure or discomfort with use; and objections regarding smell, texture, or type of material. Some participants reported they did not believe condoms were effective in preventing HIV. There were participants who also thought that condoms were not necessary when a partner was considered trustworthy, as shown by the statements:

I think sex with a condom is not unpleasant, it's better, it brings you peace, because you will be safer, you won't regret or worry about it later [...] And I think condom is nice because it prevents babies too, not just diseases ( $\mathrm{PO}_{4}$ ).

We were using drugs, and out of the blue it happened, we had sex. I wanted to be with him, then we had it. It happened at his house. We started to take off our clothes in his bedroom, and there was no condom at all, nothing (P2O).

It [condom] is nasty. If I must use it, when the lights are off, I take it off [...] I don't think it [condom] protects me, I think that what protects me is God (Po2).

The times when I did not use condoms were because I knew the girl, I knew she didn't have HIV. I trusted her, and I felt safe because of that (P19).

Comparing these answers with participants' scores in the Condom Self-Efficacy Scale, we observed that interviewees with the highest scores reported they considered condoms easy to use and accessible. These individuals thought condoms to be safe and viewed themselves as capable of performing protective behaviors. For participants with the lowest scores, the main barriers to condom use were impulsivity or being in the heat of the moment, loss of pleasure, discomfort, substance use, and unavailability of condoms. Other difficulties in condom use included the inability to put on a condom, condom breakage, and slippage. Individuals also reported difficulties in demanding condom use from a partner when having sex for money or drugs. 
I was drunk at the time, you know. I did not even think to use it. When I realized, it was too late. I had a condom at the time in my wallet, but I was stoned drunk, you know. In these situations, I do not even think about it (P33).

Once I had no condom with me, and it was late at night, so I could not buy it. That is why I did not use it. But if I had at least one in my pocket, I would have used it (P11).

I lose sensitivity when using it [condom]. I cannot feel a woman's warmth. Besides, when I put it on, it does not do well. Once it happened to slip inside the vagina, it was not nice at all. So, I do not use it (P34).

For people who use crack and cocaine, like me, things are a bit complicated. The guy offers you the drug, and demands to have sex without a condom, so you cannot deny it. We have sex without a condom, so I can smoke the drug. There is no way (PO7).

\section{Discussion}

In this study, we assessed the relationship between health beliefs and behaviors among substance users, aiming to critically comprehend aspects of the HIV vulnerability affecting this population. Social, programmatic, and individual vulnerabilities operate synergistically, reducing autonomy and rendering communities susceptible to harm. Thus, analysis on factors, such as beliefs and health behaviors, may contribute to the development of HIV prevention strategies, accounting for the characteristics of mental health services.

Our findings indicated no significant association between HIV perceived severity and HIV exposure among the participants. This finding is consistent with previous studies. Colyer et al. (2018) conducted a prospective behavioral cohort study with 497 men who have sex with men, from Vancouver, Canada. By applying a multivariable statistical analysis, the authors found no association between low HIV perceived severity and crystal methamphetamine use (considered in the study as a correlate of unsafe sex). Similar results were obtained by Levy et al. (2017). They investigated the correlation between low perceived severity of HIV (due to optimistic beliefs about HIV treatment) and unprotected sex. The authors collected data from a longitudinal study with black men who have sex with men, in six American capitals. No statistically significant association was identified between the variables among uninfected participants.

Thus, we do not recommend targeting HIV perceived severity as a strategy for HIV prevention. We also consider this strategy to be ethically inadequate, given it may lead to the stigmatization of vulnerable communities. Stigma can be defined as an undesirable mark or attribute, which confers a derogatory value to individuals, subjecting them to discrimination. When emphasizing the aversiveness of STIs, fear-based health campaigns reinforce stereotypes and contribute to misconceptions about diseases. A study conducted by Kemp et al. (2019), with Afro-American women, indicates that HIV stigmas block access to diagnosis, hinder the use of preventive methods, as well as impair adherence to treatments. 
It must be highlighted that CAPSad patients are additionally subject to stigmas due to substance use. Substance users may be considered intrinsically dangerous and unreliable, and their behavior may be perceived as a character flaw, not a health condition. Health professionals should be aware of these stereotypes. They may feel less motivated in delivering prevention and treatment for substance users, believing they will not be adherent or that they will not modify their behavior. This exclusion process, when perceived by substance users, causes them to distance themselves from health services, which reinforces their condition.

In our study, one of the participants illustrates how stigma regarding HIV/aids and substance use affects these individuals. As she stated:

I am addicted to crack cocaine, and I suffer a lot of prejudice. [...] If I get HIV, I will kill myself. Imagine if my community knew that, besides the addiction, I even had HIV? You know what I mean? I am not invited to be with other people, because I am a crack cocaine user. Can you imagine being a crack user and also with the HIV virus? Who is going to invite a person like this inside one's house? (P19).

In contrast, our data indicated a marginally significant negative association between condom use self-efficacy and HIV exposure within the sample (i.e., the higher the self-efficacy for condom use, the lower the exposure to HIV). This is in line with previous studies. Dawson et al. (2019) assessed the association between resilience, condom use self-efficacy, internalized homophobia, and unprotected anal sex among black men who have sex with men in New York City. The authors concluded that only increased levels of condom use self-efficacy were correlated with decreased unprotected anal sex. They highlight that condom use could also be influenced by peer norms, fear of rejection, and coercion.

In another study, the relationship between condom use self-efficacy and HIV risk behaviors was evaluated by Khumsaen and Stephenson (2017). The authors assessed young Thai men who have sex with men, recruited through Facebook for a self-administered anonymous survey. Participants with higher self-efficacy were more likely to use a condom at recent anal intercourse (expressed by an odd ratio of 1.13). They also found that participants who perceived fewer barriers to condom use were more likely to have safer sex (odd ratio of 0.84); and the more barriers they perceived, the more likely they were to have drunk sex (odd ratio of 1.17).

As shown by Table 2, 56.4\% of the participants stated not having received instructions in CAPSad regarding condom use. Interventions aiming for self-efficacy are grounded on promoting autonomy, a central programmatic principle of open-to-community health services. Thus, we suggest that developing self-efficacy may be applied in CAPSad services as a strategy to reduce HIV vulnerability. Self-efficacy can be developed by targeting the perceived benefits 
and barriers to condom use identified in our study. The main barriers reported to condom use, in our study, were: partner's trustworthiness; impulsive behavior; loss of pleasure; discomfort with use; exchange of sex for drugs/money; not having a condom available; and inability to put a condom, leading to breakage, slippage or no use at all.

Hence, we firstly recommend that psychologists working at CAPSad services instruct substance users on the misconceptions about serostatus. It is paramount to identify and clarify stereotypes surrounding HIV/aids to promote informed decision-making among CAPSad users. Secondly, psychologists may also instruct individuals that condom slippage and breakage issues can be managed by correct handling. Correct handling can even be helpful for discomfort with condoms. Psychologists should assess other difficulties as well.

Participants also pointed the consumption of substances as a main barrier to condom use. They believed this consumption interferes with condom usage mostly in two ways: by impairing their judgment/self-control when having sex while on drugs and by making them exchange unprotected sex for drugs/money. Participants did not report using injectable drugs. The association between substance consumption and condom self-efficacy can be regarded as supporting the benefits of integrating primary and secondary care. In this aspect, CAPSad functions as a strategic point of attention. CAPSad is also strategic for general healthcare because these centers can access hard-to-reach populations. As shown in this study, many participants were homeless, a condition that increases their vulnerability to HIV. Therefore, delivering integral care in CAPSad may be particularly beneficial for these individuals.

Besides targeting benefits and barriers to condom use, sharing precise information about HIV infection must be considered when strengthening autonomy. As shown by Gomes et al. (2017), for the Brazilian population, a higher level of knowledge about HIV is found to be positively associated with safer sexual behaviors. In our study, we observed an important lack of knowledge regarding HIV/aids. Table 1 shows that only $15.4 \%$ of individuals have completed higher school, and Table 2 points that $53.8 \%$ of individuals have not received guidance at CAPSad about HIV testing and how to do it. Furthermore, as shown by qualitative interviews, while some participants knew that, if not properly treated, HIV is fatal, others believed there is a cure for it.

CAPSad users must also be instructed about other preventive methods besides condoms. As shown by Table 2, 35 participants (89.7\%) reported they never heard about Post-Exposure Prophylaxis (PEP) and Pre-Exposure Prophylaxis (PrEP). Such prophylaxes are highly effective in preventing HIV infection and are available for vulnerable populations in the Brazilian public health system. Thus, psychologists should instruct CAPSad users about the broad range of preventive methods, complementary to condom, so that informed decision-making can be made. 


\section{Limitations of the study}

Our study has limitations. The first limitation is the size of our sample. The number of outpatients meeting the selection criteria of a stable bond with the institution was relatively small, hindering the recruitment of more participants. Therefore, results must be taken with caution, since small samples may not truly represent the source population. Second, the employed convenience sampling method can be prone to errors, such as selection bias. In non-probabilistic samples, individuals do not have equal odds of being recruited, limiting the ability to make inferences from the data.

Third, the observational and non-longitudinal nature of this study did not allow for causal inferences regarding the relationships between variables. Data may indicate associations between certain variables, but one cannot exclude the possibility of these being random associations. Fourth, the Perceived Severity Scale and Condom Self-Efficacy Scale were not originally designed for a population of substance users. Nonetheless, we decided to use it, given that there were no specific Brazilian instruments available to assess perceived HIV severity and condom use self-efficacy in substance users.

Fifth, another important limitation of our study refers to the pre-existing evidence found in the literature. This evidence was mostly obtained from samples composed of men who have sex with men. They differ from our sample, which also includes women (whose sexual practice involves partners of the same and of the other sex).

In this research, issues concerning sampling and data collection were addressed by initially selecting ten individuals for the pilot study. This pilot study was conducted to verify how well CAPSad outpatients comprehended the instruments and instructions used in the present study. These participants were not included in the final sample. Qualitative analysis was also used as a strategy to counterbalance research limitations, by complementing the instruments with exploratory data. We recommend that future studies recruit larger and homogeneous samples, to obtain more statistically significant results. Furthermore, we encourage researchers to validate or develop psychometric instruments to assess condom use self-efficacy in adults and substance users, given the deficit of such resources in the Brazilian scientific literature. 


\section{References}

Bandura, A. (1977). Self-efficacy: Toward a unifying theory of behavioral change. Psychological Review, 84(2) 191-215. https://doi.org/10.1037/0033-295X.84.2.191

Baptista, C. J., Dourado, I., de Andrade, T. M., Brignol, S., Bertoni, N., Bastos, F. I., \& The Brazilian Multicity Study Group on Drug Misuse. (2018). HIV prevalence, knowledge, attitudes, and practices among polydrug users in Brazil: A biological survey using respondent driven sampling. AIDS and Behavior, 22, 2089-2103. https://doi.org/10.1007/s10461-017-1812-8

Bardin, L. (2011). Análise de conteúdo. Almedina.

Brasil (Ministério da Saúde). (2019). Campanha de IST: Sem camisinha, você assume esse risco. http:// www.aids.gov.br/pt-br/campanha/2019-campanha-de-ist-sem-camisinha-voce-assumeesse-risco

Colyer, S., Lachowsky, N. J., Cui, Z., Zhu, J., Armstrong, H., Taylor, M., Edward, J., Olarewaju, G., Hogg, R. S., Roth, E. A., \& Moore, D. M. (2018). HIV treatment optimism and crystal methamphetamine use and initiation among HIV-negative men who have sex with men in Vancouver, Canada: A longitudinal analysis. Drug and Alcohol Dependence, 185, 67-74. https://doi.org/10.1016/j. drugalcdep.2017.12.004

Dawson, E., Mendoza, M. C., Gaul, Z., Jeffries, W. J., Sutton, M. Y., \& Wilson, P. (2019). Resilience, condom use self-efficacy, internalized homophobia, and condomless anal sex among black men who have sex with men, New York City. PLoSOne, 14(4), e0215455. https://doi.org/10.1371/ornal.pone.0215455

Dela Coleta, M. F. (2003). Escalas para medida das crenças em saúde: Construção e validação. Avaliação Psicológica, 2(2), 111-122. http://pepsic.bvsalud.org/scielo php?script=sci_arttext \&pid $=$ S1677-04712003000200003

Furtado R. N., Grincenkov, F. R. S., \& Martins, L. F. (2020). Gravidade percebida e vulnerabilidade ao HIV: Revisão sistemática da literatura. Subjetividades, 20(2) 1-12. https://doi.org/10.5020/23590777. rs.v20i2.e10166

GBD 2017 Risk Factors Collaborators. (2018). Global, regional, and national comparative risk assessment of 84 behavioural, environmental and occupational, and metabolic risks or clusters of risks for 195 countries and territories, 1990-2017: A systematic analysis for the Global Burden of Disease Study 2017. Lancet, 392(10159), 1923-1994. https://doi.org/10.1016/S0140-6736(18)32225-6

Gomes, R. M., Ceccato, M. B., Kerr, L. R. S., \& Guimarães, M. C. (2017). Fatores associados ao baixo conhecimento sobre HIV/AIDS entre homens que fazem sexo com homens no Brasil. Cadernos de Saúde Pública, 33(10), 1-15. https://doi.org/10.1590/0102-311x00125515

Hanna, K. M. (1999). An adolescent and young adult condom self-efficacy scale. Journal of Pediatric Nursing, 14(1), 59-66. https://doi.org/10.1016/S0882-5963(99)80061-X

Kemp, C. G., Lipira, L., Huh, D., Nevin, P. E., Turan, J. M., Simoni, J. M., Cohn, S. E., Bahk, M., Berzins, B., Andrasik, M., Mugavero, M. J., \& Rao, D. (2019). HIV stigma and viral load among African-American women receiving treatment for HIV. AIDS, 33(9), 1511-1519. https://doi.org/10.1097/ qad.0000000000002212

Khumsaen, N., \& Stephenson, R. (2017). Beliefs and perception about HIV/AIDS, self-efficacy, and HIV sexual risk behaviors among young Thai men who have sex with men. AIDS Education Prevention, 29(2) 175-190. https://doi.org/10.1521/aeap.2017.29.2.175 
Levy, M., Phillips, G., Magnus, M., Kuo, I., Beauchamp, G., Emel, L., Hucks-Ortiz, C., Hamilton, E. L., Wilton, L., Chen, I., Mannheimer, S., Tieu, H.-V., Scott, H., Fields, S. D., del Rio, C., Shoptaw, S., \& Mayer, K. (2017). A longitudinal analysis of treatment optimism and HIV acquisition and transmission risk behaviors among black men who have sex with men in HPTN 061. AIDS and Behavior, 21(1) 2958-2972. https://doi.org/10.1007/s10461-017-1756-z

Metzger, D. S. (1993). The risk assessment battery (RAB): Validity and reliability. In National Institute of Allergy and Infectious Diseases (NIAID) (Org.), Sixth annual meeting of the national cooperative vaccine development groups for AIDS (pp. 945-952). NIAID.

Pechansky, F., Metzger, D., \& Hirakata, V. (2002). Adaptation and validation of a questionnaire about risk behaviors for AIDS among drug users. Revista Brasileira de Psiquiatria, 24(3), 130-136. https://doi.org/10.1590/S1516-44462002000300006

Rosenstock, I., Strecher, V. J., \& Becker, M. H. (1994). The health belief model and HIV risk behavior change. In R. J. DiClemente, J. Ralph, \& J. L. Peterson (Ed.), Preventing AIDS: Theories and Methods of Behavioral Interventions (pp. 5-25). Springer Science. https://doi.org/10.1007/978-1-4899-1193-3_2

Sousa, C. S., Castro, R. C., Pinheiro, A. N., Moura, E. R., Almeida, P. C., \& Aquino, P. S. (2017). Adaptação transcultural e validação da condom self-efficacy scale: Aplicação em adolescentes e adultos jovens brasileiros. Revista Latino-Americana de Enfermagem, 25, 1-9. https://doi. org/10.1590/1518-8345.1062.2991

United Nations Joint Programme on HIV/AIDS (UNAIDS). (2020). UNAIDS Data 2020. UNAIDS.

United Nations Office on Drugs and Crime (UNODC). (2020). World Drug Report 2020. UNODC.

Editorial board

Editor-in-chief

Cristiane Silvestre de Paula

\section{Associated editors}

Alessandra Gotuzo Seabra

Ana Alexandra Caldas Osório

Luiz Renato Rodrigues Carreiro

Maria Cristina Triguero

Veloz Teixeira

\section{Section editors}

\section{"Psychological Evaluation"}

Alexandre Luiz de Oliveira Serpa

André Luiz de Carvalho

Braule Pinto

Luiz Renato Rodrigues Carreiro

Vera Lúcia Esteves Mateus

\section{"Psychology and Education"}

Alessandra Gotuzo Seabra

Carlo Schmidt

Regina Basso Zanon

\section{"Social Psychology and \\ Population's Health" \\ Enzo Banti Bissoli \\ Marina Xavier Carpena}

"Clinical Psychology"

Carolina Andrea Ziebold Jorquera

Julia Garcia Durand

Natalia Becker

\section{"Human Development"}

Maria Cristina Triguero

Veloz Teixeira

Rosane Lowenthal

\section{Technical support}

Maria Fernanda Liuti

Bento da Silva

Camila Fragoso Ribeiro
Editorial production

Publishing coordination

Ana Claudia de Mauro

\section{Editorial interns}

Élcio Carvalho

Júlia Lins Reis

Pietro Menezes

\section{Language editor}

Daniel Leão

\section{Layout designer}

Acqua 